\title{
Thermal characterization of archaeological pot sherds recently excavated in Nedunkur, Tamilnadu, India
}

\section{(Caracterização térmica de fragmento cerâmico arqueológico recentemente excavado em Nedunkur, Tamilnadu, India)}

\author{
S. Meyvel $^{1}$, P. Sathya ${ }^{2}$, G. Velraj ${ }^{3}$ \\ ${ }^{1}$ Department of Physics, Mahendra Institute of Technology, Namakkal, Tamilnadu, India \\ ${ }^{2,3}$ Department of Physics, Periyar University, Salem, Tamilnadu, India \\ mail2meyvel@yahoo.co.in, sathya_physics@yahoo.com,gvelraj@yahoo.co.uk
}

\begin{abstract}
The archaeological pottery sherds excavated recently in Nedunkur, Tamilnadu, were analysed using Thermogravimetric (TG) and Differential Thermal analysis (DTA) with an objective of identifying the mineralogical characteristics of the raw materials used for their production. Besides, the thermal reactions associated over the linear temperature ramp from room temperature to $1200{ }^{\circ} \mathrm{C}$ in an inert atmosphere were also realized by TG-DTA. The characterization studies were able to indicate the conditions of firing process adopted and firing temperature attained by the artisans at the time of manufacture.
\end{abstract}

Keywords: archaeological pottery, firing temperature and TG-DTA.

Resumo

Os fragmentos cerâmicos arqueológicos escavados recentemente em Nedunkur, Tamilnadu, foram examindos usando análise termogravimétrica (TG) e análise térmica diferencial (ATD) com a finalidade de identificar as características mineralógicas dos materiais usados em sua produção. Alem disso, as reações térmicas associadas no aquecimento linear de temperatura ambiente até $1200{ }^{\circ} \mathrm{C}$ em atmosfera inerte foram observadas por TG-ATD. Os estudos de caracterização possibilitaram indicar as condições do processo de queima adotados e as temperaturas de queima adotadas pelos artesãos quando da fabricação.

Palavras-chave: fragmentos arqueológicos, temperaturas de queima, TG-ATD.

\section{INTRODUCTION}

Thermal modifications of clay minerals in respect to their crystalline structure during the firing of pottery are important for appreciating and understanding their manufacturing processes. The clay mineral compositions and characteristic reactions such as dehydroxylation, decomposition and transformation occurring during the course of firing are also the criteria for reconstruction of former production conditions.

The fired clay products can be examined through the application of thermogravimetric (TG) and differential thermal analysis (DTA). TG-DTA is a very important characterization method used for the identification of the reaction process as well as the properties of the raw materials concerned. Thermo gravimetric analysis reveals the change in the sample weight with respect to the changes in temperature as well as in thermodynamic properties. DTA curves enable to detect the exo - endo-thermic peaks (effects due to gain/ loss of enthalpy) occurring in the sample when undergoing to controlled heating compared to an inert reference material.

TG-DTA analysis is also an indispensable tool in discovering some special technological features of ancient pottery [1]. By thermal analysis the characterization of archaeological ceramics and pottery can be further improved especially concerning the firing temperature and/or presence of mineral phases of the experimental sample of sherds [2].

Hence, in the present study attention has been fixed on the thermal characterization (TG-DTA) of five archaeological pottery sherds NDR1, NDR2, NDR3, NDR4 and NDR5 excavated from Nedunkur, Ramanathapuram District, Tamilnadu, India and the results of the measurements were used for the estimation of the firing temperature.

\section{EXPERIMENTAL TECHNIQUES}

Thermogravimetric and differential thermal analysis were carried out on the as received state (ARS) sample of five potsherds in SDT Q $600 \mathrm{~V} 8.3$ thermal analyzer. The operating conditions of thermo gravimetric and differential thermal analyzes instruments are given in Table I. The experiment was done by heating the samples from room temperature to $1200{ }^{\circ} \mathrm{C}$ at $20{ }^{\circ} \mathrm{C} / \mathrm{min}$ in a static nitrogen atmosphere. 
Table I - Operational setting for TG-DTA.

[Tabela I - Condições experimentais para ATG-ATD.]

\begin{tabular}{ll}
\hline System Design & Horizontal balance and Furnace \\
Balance design & Dual beam (growth compensated) \\
Balance sensitivity & $0.1 \mu \mathrm{g}$ \\
Furnace type & Bifilar wound \\
Thermo couple & Pt/Pt-Rh (type R ) \\
Atmosphere & Nitrogen \\
Sample pans & Platinum $: 40 \mu \mathrm{L}, 110 \mu \mathrm{L}$ \\
Software & Alumina $: 40 \mu \mathrm{L}, 90 \mu \mathrm{L}$ \\
\hline
\end{tabular}

\section{Thermal characterization}

Thermal analysis is used as the best characterization method in studies related with the determination of firing temperature of archaeological ceramics [3, 4]. In thermogravimetric analysis, the experimental pottery sherds on reheating have shown significant mass loss due to dehydration (room temperature-200 ${ }^{\circ} \mathrm{C}$ ), decomposition of hydroxyls $\left(400-650^{\circ} \mathrm{C}\right)$ and decomposition of calcite $(700-$ $800{ }^{\circ} \mathrm{C}$ )

$$
\mathrm{CaCO}_{3} \text { (calcite) } \rightarrow \mathrm{CaO} \text { (calcium oxide) }+\mathrm{CO}_{2}
$$

In different temperature intervals, the mass loss is not uniform and it is due to the fact that the pottery sherds may suffer change in their properties. The mass loss found is more in dehydration and less in dehydroxylation.

In differential thermal analysis, exo/endo thermic peaks appearing in all the specimens at different temperature intervals are described as follows: $1-50-200{ }^{\circ} \mathrm{C}$ : a broad endothermic peak in this range is due to the loss of hygroscopic water in the sample; $250-500{ }^{\circ} \mathrm{C}$ : a broad exothermic peak in this range is due to the combustion of organic material present in the clay of the pottery. The area of the peak depends on the amount of organic material contained in the clay; $550-600^{\circ} \mathrm{C}$ : an endothermic peak here indicates the loss of chemically combined hydroxyl water by clay minerals such as kaolin. When this peak is present, it shows that the pottery has not been heated above this temperature previously; when it is absent, the pottery has been fired above this temperature.

\section{RESULTS AND DISCUSSION}

The TG-DTA curves of five archaeological pottery sherds coded as NDR1, NDR2, NDR3, NDR4 and NDR5 collected from Nedunkur site at different depths are shown in Figs. 1-5.

The weight loss percentage resulted in the thermal reactions between the sample sherds and the reference material during there firing from room temperature to $1200{ }^{\circ} \mathrm{C}$ is presented in Table II.

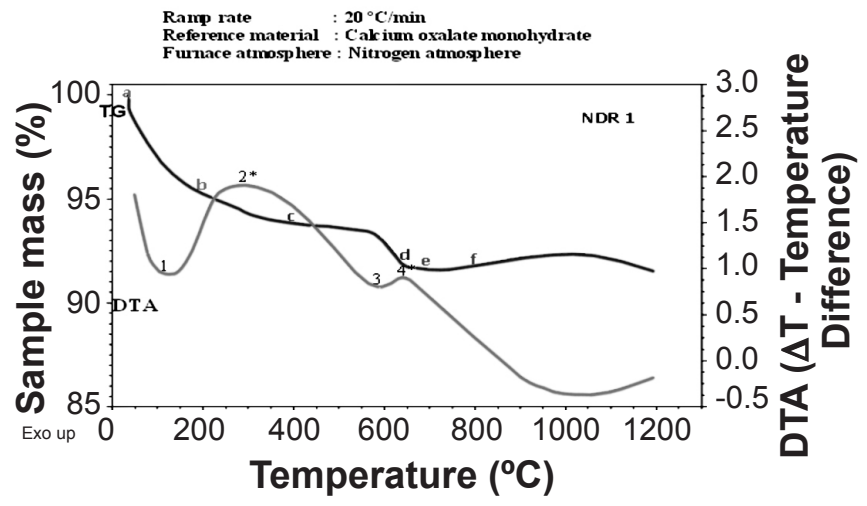

Figure 1: Characteristic TG-DTA curve of pot sherd NDR1.

[Figura 1: Curvas características termogravimétrica e térmica diferencial de fragmentos cerâmicos NDR1.]

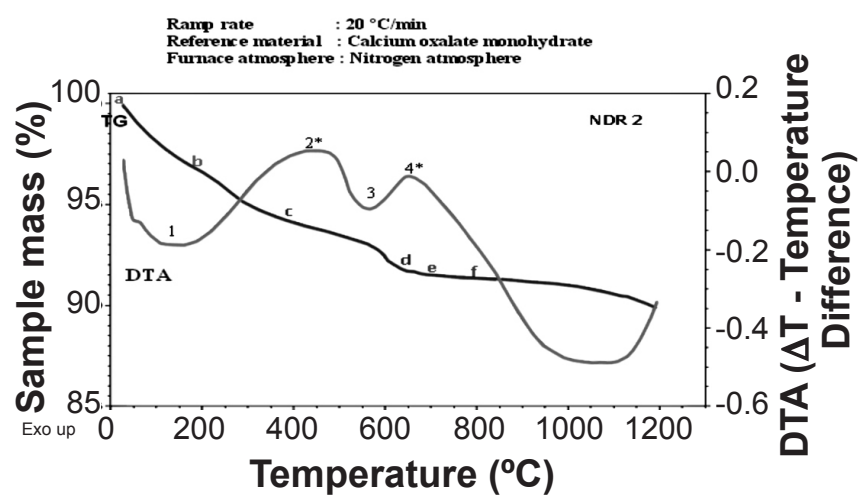

Figure 2: Characteristic TG-DTA curve of pot sherd NDR2. [Figura 2: Curvas características termogravimétrica e térmica diferencial de fragmentos cerâmicos NDR2.]

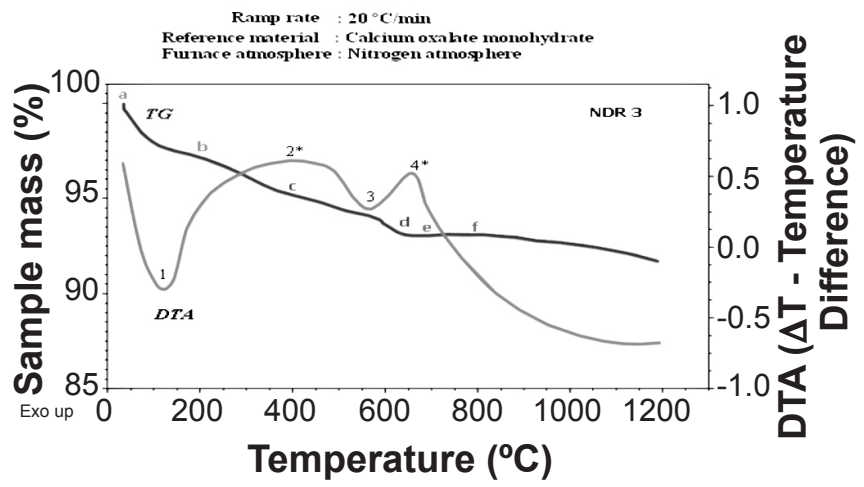

Figura 3: Characteristic TG-DTA curve of pot sherd NDR3.

[Figura 3: Curvas características termogravimétrica e térmica diferencial de fragmentos cerâmicos NDR3.]

From thermogravimetric curves, it is observed that the mass loss of the archaeological potteries on increasing the temperature from room temperature to $1200{ }^{\circ} \mathrm{C}$ is not gradual but the variation is different in different temperature regions. The TG curves of the shreds showed gradual weight loss from ' $a-b$ ' due to dehydration of water molecules in the temperature range $30-200{ }^{\circ} \mathrm{C}$. Further, the curve exemplify decrease in weightloss from $400-650{ }^{\circ} \mathrm{C}$ between ' $c$ ' and ' $\mathrm{d}$ ' 


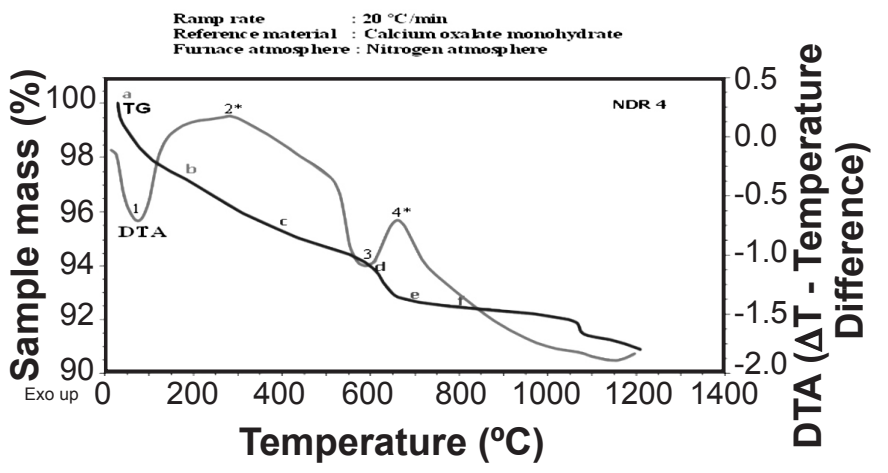

Figura 4: Characteristic TG-DTA curve of pot sherd NDR4. [Figura 4: Curvas características termogravimétrica e térmica diferencial de fragmentos cerâmicos NDR4.]

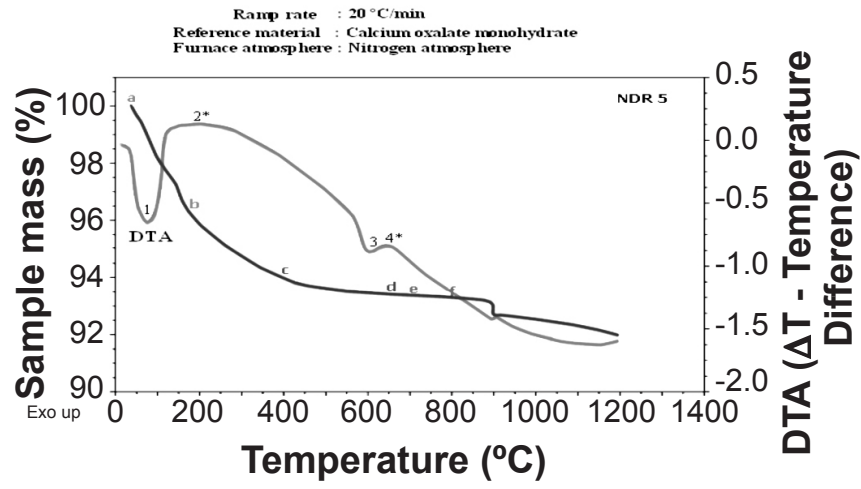

Figura 5: Characteristic TG-DTA curve of pot sherd NDR5.

[Figura 5: Curvas características termogravimétrica e térmica diferencial de fragmentos cerâmicos NDR5.]

representing the decomposition of hydroxyls. However, the curve 'e-f' is thermally stable with zero weight loss in the region $700-800{ }^{\circ} \mathrm{C}$ indicates the absence of calcite in the samples of interest. The DTA curves of these sherds show diverse endothermic and exothermic peaks at different temperatures as given in Table III.

It has been stated that the endothermic peak around 100 to $200{ }^{\circ} \mathrm{C}$ represents the presence of hygroscopic water i.e. physically absorbed water [5]. So, the endothermic peak observed between $100-200{ }^{\circ} \mathrm{C}$ in DTA curves characterize the hygroscopic water in the samples NDR1, NDR2, NDR3,
Table III - Differential thermal analytical data of Nedunkur sherds.

[Tabela III - Dados de ATD de fragmentos cerâmicos de Nedunkur.]

\begin{tabular}{|c|c|c|}
\hline Sherd code & Peak No. & $\begin{array}{c}\text { Peak } \\
\text { Temperatures } \\
\left({ }^{\circ} \mathrm{C}\right)\end{array}$ \\
\hline NDR1 & $\begin{array}{l}1 \\
3^{2 *} \\
4 *\end{array}$ & $\begin{array}{l}130 \\
300 \\
580 \\
640\end{array}$ \\
\hline NDR2 & $\begin{array}{l}1 \\
2 * \\
3 \\
4 *\end{array}$ & $\begin{array}{l}140 \\
450 \\
550 \\
650\end{array}$ \\
\hline NDR3 & $\begin{array}{l}1 \\
2 * \\
3 \\
4 *\end{array}$ & $\begin{array}{l}120 \\
400 \\
550 \\
650\end{array}$ \\
\hline NDR4 & $\begin{array}{l}1 \\
2 * \\
3 \\
4 *\end{array}$ & $\begin{array}{c}80 \\
290 \\
580 \\
655\end{array}$ \\
\hline NDR5 & $\begin{array}{l}1 \\
3^{2 *} \\
4 *\end{array}$ & $\begin{array}{c}75 \\
250 \\
610 \\
630\end{array}$ \\
\hline
\end{tabular}

* Exothermic peak

NDR4 and NDR5 respectively. The broad exothermic peak in the temperature region $250-500{ }^{\circ} \mathrm{C}$ is due to the combustion of organic materials present in the potteries $[6,7]$. So the broad exothermic band found in the range of temperature $250-500{ }^{\circ} \mathrm{C}$ in the characteristic DTA curves of Nedunkur samples represent combustion of organic materials present in the clay of potteries. The endothermic

Table II - TG data of Nedunkur sherds.

[Tabela II - Dados de ATG de fragmentos cerâmicos de Nedunkur.]

\begin{tabular}{cccccc}
\hline & \multicolumn{4}{c}{ Weight loss $(\%)$} & Total \\
\cline { 2 - 5 } Sherd code & $\begin{array}{c}\text { Dehydration } \\
\left(30-200^{\circ} \mathrm{C}\right)\end{array}$ & $\begin{array}{c}\text { Decomposition of } \\
\text { hydroxyls } \\
\left(400-650^{\circ} \mathrm{C}\right)\end{array}$ & $\begin{array}{c}\text { Decomposition of } \\
\text { calcite } \\
\left(700-800^{\circ} \mathrm{C}\right)\end{array}$ & $\begin{array}{c}\text { Residual mass } \\
(\%)\end{array}$ & $\begin{array}{c}\text { weight } \\
\text { loss } \\
(\%)\end{array}$ \\
\hline NDR1 & 5.0 & 2.3 & 0 & 91.51 & 8.49 \\
NDR2 & 3.9 & 2.5 & 0 & 89.84 & 10.16 \\
NDR3 & 3.0 & 2.0 & 0 & 91.66 & 8.34 \\
NDR4 & 3.0 & 2.2 & 0 & 91.88 & 8.12 \\
NDR5 & 4.4 & 0.5 & 0 & 87.24 & 12.76 \\
\hline
\end{tabular}


peak appearing near the temperature $600{ }^{\circ} \mathrm{C}$ is attributed to the decomposition of kaolinite [8]. So, the decomposition of kaolinite was evidenced by the appearance of endothermic peak in all the Nedunkur sherds very close to $600{ }^{\circ} \mathrm{C}$ respectively. The band on decomposition of kaolinite is the indication that the pottery is not fired above $800{ }^{\circ} \mathrm{C}$ [7]. Referring the report by the authors cited above it is believed that all Nedunkur pottery fragments NDR1, NDR2, NDR3, NDR4 and NDR5 respectively were fired below $800{ }^{\circ} \mathrm{C}$. All the shreds have showed larger mass loss at dehydration, and relatively lesser mass loss at dehydroxylation. The Nedunkur sherds of the present investigation have weight loss of 5.0\%, $3.9 \%, 3.0 \%, 3.0 \%$ and $4.4 \%$ respectively between the room temperature to $200{ }^{\circ} \mathrm{C}$ due to dehydration of water. It has been stated that weight loss occurred in the region of temperature $400-650{ }^{\circ} \mathrm{C}$ is attributed to decomposition of hydroxyls [9, 10]. Hence, the samples of the study NDR1, NDR2, NDR3, NDR4 and NDR5 showed less than 3\% of weight loss during $400-650^{\circ} \mathrm{C}$ as a result of decomposition of hydroxyls. In agreement with previous statements $[9,10]$, the Nedunkur samples are considered to be fired in between $700-800{ }^{\circ} \mathrm{C}$ as they are not possessing calcite mineral in their composition as evidenced by the absence of peak in this respective region of temperature.

\section{CONCLUSIONS}

The five archaeological pottery sherds were characterized by thermal analysis using TG curves, and exothermic and endothermic peaks appeared in DTA curves. From the analysis, it is estimated that the all the Nedunkur sherds were fired below $800{ }^{\circ} \mathrm{C}$ by the artisans at the time of manufacture. Thermal analysis also reveals the percentage of mass loss due to dehydration, dehydroxylation, and the combustion of organic material contained in the clay used to make the pottery sample studied in the present investigation. The residual mass in TG of the sherds of the study varied from 97.1 to $83.58 \%$. The variation in residual mass clearly indicates the difference in mineralogy, the amount of moisture content and the level of organic material. In all the sherds the residual mass is less than the initial mass indicates that the weight loss was occurred during the controlled process of firing. The amount of residual mass is mainly controlled by transformation of minerals, dehydration, the amount of combustible material mainly organic materials present and temperature. But in the present investigation major weight loss was caused by dehydration process and it played major role in determining the final residual mass.

\section{REFERENCES}

[1] A. Krapukaitytè, S. Tautkus, A. Kareiva, E. Zalieckienè, Thermal analysis - a powerful tool for the characterization of pottery, Chemija 19 (2008) 4-8.

[2] F. Veniale, in Analytical Methodologies for the Investigation of Damaged Stones, Advanced Workshop, Pavia, Italy (1990) 3-19.

[3] J. P. Roberts, Determination of the firing temperature of ancient ceramics by measurement of thermal expansion Archaeometry 6 ( 2007) 21-25.

[4] M. Daszkiewicz, J. Raabe, The ceramics cultural Heritage, Ed. P. Vincenzini, Monographs in Materials and Society 2, Techna, Faenza, Italy (1995) 349.

[5] L. Paama, I. Pitkanen, P. Peramaki, Analysis of archaeological samples and local clays using ICP-AES, TGDTG and FTIR techniques, Talanta 51 (2000) 349-357.

[6] S. J. G. Sousa, J. N. F. Holanda, Thermal transformations of red wall tile pastes, J. Thermal Analysis and Calorimetry 87 (2007) 423-428.

[7] G. Clerk, B. F. Leach, S. O' Conner, Islands of inquiry: Colonization, Seafaring and the Archaeology of Maritime Landscape, papers in honor of Atholl Anderson, Terra Australia, Australian National University Press (2008) 435452.

[8] Mohamed Hajjaji, Salah kacim, Mohamed Boulmane, Mineralogy and firing characteristics of clay from the valley of Ourika, Appl. Clay Sci. 21 (2002) 203-212.

[9] Angela Traini, Lorena C. Giannossa, P. Ubbriaco, Annarosa Mangone, Maria, D. De Filippis, R. Laviano, The reason of the collapse an ancient kiln in egnazia from mineralogical and thermal analysis of ceramic finds, $\mathbf{J}$. Thermal Analysis and Calorimetry 92 (2008) 337-344.

[10] V. A. Drebushchak, L. N Mylnikova, T. N Drebushchak, V. V. Boldyrev, The investigation of ancient pottery Application of thermal analysis, J. Thermal Analysis and Calorimetry 82 (2005) 617-626.

(Rec. 11/08/2011, Ac. 02/10/2011) 